\title{
DAKWAH KEAGAMAAN, BUKAN UNTUK ORANG DESA!
}

\author{
Religion Preach, Not for Villagers \\ Oleh: Saprillah* \\ *Peneliti pada Balai Penelitian dan Pengembangan Agama Makassar \\ Jl. A. P. Pettarani No.72 Makassar \\ E-mail: saprillah@,vahoo.co.id
}

\begin{abstract}
Abstrak
Penelitian tindakan kelas ini bertujuan untuk menemukan tingkatpretasi Pendidikan Agama Islam (PAT) dengan menggunakan proses pembelajaran Aktif, Interaktif, dan Menyenangkan. Pembelqjaran dibentuk dengan tiga formasi, yaitu Formasi Pembelqjran Aktif dan Interaktif; Aktif dan Menyenangkan dan Interaktif dan Menyenangkan. Setiap formasi pembelajaran dilakukan dengan dua tahap, yaitu tahap pertama pembelajaran konvensional yang sering dilakukan oleh guru agama yang diakhiri dengan protest. Tahap kedua dilakukan dengan pembelajaran formasi di atasyang diakhir dengan postest.

Hasil penelitian menujukkan bahwa prestasi belajar siswa setelah dilakukan ketiga formasi pembelajaran tersebut meningkat. Prestasi belajar PAI siswa sebelum pembelajaran Aktif dan Interaktif, $r=5,29$ pada protest meningkat menjadi $r=9,16$ pada posttest; pada pembelajaran Aktif dan Menyenangkan protest $r=6,94$, meningkat pada postest $r=9,71$; dan pada formasi Interaktif dan Menyenangkan protest $r=6,84$ meningkat pada postest $r=9,76$. Penelitian ini merekomendasikan bahwa dalam upaya meningkatkan prestasi belajar PAI siswa yang dominan merupakan meteri pelajaran yang bersifat hafalan dibanding penalaran hendaknya menggunakan metode-metode pembelajaran yang merangsang daya hafalan setiap siswa seperti Metode Pembelajaran Aktif, Interaktif dan Menyenangkan. Selain itu, pertimbangan yang lain yang urgen untuk diperhatikan adalah pelibatan tiga jenis bentuk aktivitas belajar dalam setiap pembelajaran yaitu membaca, mengungkapkan hasil bacaan, dan menulis, khususnya pada pembelajaran PAI yang dominan merupakan meteri hafalan.

Kata Kunci: pembelajaran, aktif, interaktif, menyenangkan
\end{abstract}

\section{Abstract}

This article is a summary of the result of the research on the religious proselytizing in underdeveloped areas. Research was conducted in Buae village, Watangpulu sub district. Data was collected through interview and observation.

Result shows that religious proselytizing by state institution such as Religious Affair Departmentand other social religious institution was not managed to and did not reach remote areas. It had an implication to the religious proselytizing stagnation in those areas.

Therefore, writer recommends adaptive religious proselytizing be conducted in such areas. This adaptive model should start with mapping on current and forecasted issues in targeted community. The proselytizer should have, at least, complete map of targeted areas. To make them easier transform their knowledge, They should know the language and economic, social, cultural practices belonged to community. The proselytizer, therefore, should not be a stranger in his/her community. He/she should be diligent to "read" the social situation and the current community behaviour deviation.

Key words: religious proselytizing, adaptive proselytizing.

\section{PENDAHULUAN}

A gama merupakan kebutuhan manusia yang sangat primordial. Pemenuhan kebutuhan atas agama dapat meningkatkan derajat dan kualitas kemanusiaan seseorang dan sekaligus mendinamisasi suatu masyarakat menuju peradabanyang agung. Emile Durkheim mengatakan bahwa fungsi agama adalah untuk menyatukan spiritualitas manusia dengan "yang sakral" untuk membangun moralitas tunggal. Defenisi Durkheim setidaknya mengisyaratkan bahwa agama merupakan elemen penting dalam membangun suatu masyarakat.

Indonesia adalah salah satu model negara di dunia yang menjadikan nilai agama sebagai basis ideologis dan fllosofisnya (meski tidak menjadikan identitas formal agama sebagai pondasi konstitusinya). Berdasarkan hal itu, negara memiliki mandat sosial untuk memberikan pelayanan keagamaan kepada seluruh lapisan masyarakat dan seluruh belahan wilayah baik secara langsung melalui institusi negara, Departemen Agama, maupun secara tidak langsung melalui organisasi sosial keagamaan dan atau tokoh-tokoh agama (para ulama, dai dan guru-guru agama).
Visi Departemen Agama sebagai mandataris negara untuk mengelola "lalu lintas" keberagamaan di Indonesia adalah "terwujudnya masyarakat Indonesia yang taat beragama, maju, sejahtera, cerdas, serta saling menghormati antar sesama pemeluk agama dalam kehidupan bermasyarakat, berbangsa, dan bernegara dalam wadah NKRI".

Visi Departemen Agama sungguh menarik. Ia mengaitkan antara ketaatan beragama, kemajuan, dan kesejahteraan dalam konteks kebangsaan dan kenegaraan. Artinya pelayanan keagamaan harus mendorong masyarakat untuk memiliki komitmen terhadap Tuhan tanpa melupakan konteks kemanusiaan berupa ekonomi, sosial dan budaya.

Model agama yang harus dikembangkan di Indonesia (berdasarkan pada visi Departemen Agama) adalah model keagamaan progressif. Nilai-nilai keagamaan yang bersifat profetik namun tidak mematikan potensi manusiawi dalam diri manusia untuk memperjuangkan sisi humanitasnya. Nilai-nilai agama tersebut harus menjadi faktor utama atas terbentuknya masyarakat yang memiliki visi kemanusiaan berorientas ketuhanan. 
Visi Departemen Agama ini seirama dengan RPJMN 2004-2009 bidang keagamaan, dimana dua poin diantara enam program berkaitan dengan pelayanan keagamaan. Poin yang dimaksud adalah 1) program peningkatan pemahaman, penghayatan, pengamalan, dan pengembangan nilai-nilai keagamaan, 2) program peningkatan pelayanan kehidupan beragama.

Problemnya kemudian adalah apakah strategi pengembangan nilai-nilai keagamaan melalui dakwah oleh lembaga keagamaan benar-benar telah menyapa seluruh kalangan masyarakat. Apakah dakwah keagamaan telah menyentuh kepentingan di daerah pedesaan. Apalagi dalam logika pembangunan, wilayah rural acapkali tidak termasuk dalam grand design pembangunan.' Akibatnya, masyarakat desa tidak memiliki akses yang cukup untuk "merasakan" pelayanan pemerintah pusat.

Berdasarkan pada latar belakang di atas, penelitian ini mengangkat permasalahan, yaitu: bagaimana sistem pengelolaan dakwah keagamaan Islam di desa? Pertanyaan masalah ini memberi ruang bagi peneliti untuk mengeksplorasi pelayanan keagamaan departemen agama tingkat Kabupaten dan atau tingkat kecamatan (KUA) kepada masyarakat pedesaan, dan sekaligus mengeksplorasi independesi masyarakat desa dalam mengelola dakwah keagamaan di tingkat mereka.

Penelitian ini dilaksanakan di Desa Buae Kecamatan Watangpulu Kabupaten Sidrap. Pemilihan lokasi didasari pada asumsi keterjangkauan wilayah, dan keunikan demografis, dimana masyarakat Desa Buae adalah masyarakat campuran antara muslim dan komunitas Tolotang yang dianggap sebagai orang Hindu.

Penelitian merupakan penelitian kualitatif. Data diperoleh dengan melakukan wawancara mendalam ke sejumlah informan yang terkait dengan penelitian, dan melakukan observasi terhadap aktivitas masyarakat yang berkaitan dengan dakwah keagamaan.

\section{TINJAUAN PUSTAKA}

Studi mengenai dakwah keagamaan di daerah tertinggal dimaksudkan sebagai upaya untuk melihat peran negara (dalam hal ini Departemen Agama) dan masyarakat (organisasi sosial keagamaan dan personal) dalam melayani kepentingan spiritual masyarakat khususnya di daerah terpencil. Penelitian ini tidak mengasumsikan bahwa orang-orang yang hidup di pedesaan adalah mereka yang lemah tingkat keimanannya. Penekanan kajian ini adalah pelayanan departemen agama (dan organisasi sosial keagamaan) terhadap kebutuhan keagamaan masyarakat di daerah tertinggal.

Dakwah Keagamaan Sebagai Pelayanan Publik

Pengertian pelayanan dalam Kamus Umum Bahasa Indonesia adalah "hal, cara, atau hasil pekerjaan melayani". ${ }^{3}$ Pelayanan pada prinsipnya adalah usaha untuk menawarkan kepuasan kepada orang lain dengan tujuan tertentu misalnya untuk mendapatkan keuntungan. ${ }^{4}$ Normann mengajukan beberapa karakteristik pelayanan: pelayanan besifat abstrak, merupakan tindakan nyata yang berimplikasi sosial, produksi dan konsumsi pelayanan tidak terpisahkan. Pengertian yang lebih luas diungkapkan oleh Daviddow dan Utal bahwa pelayanan merupakan usaha apa saja yang dapat memenuhi kepuasan pelanggan. ${ }^{5}$

Berdasarkan pengertian-pengertian di atas, pelayanan pada prinsipnya adalah bentuk relasi antar manusia dimana satu fihak bertindak sebagai pemberi jasa pelayanan dan fihak lain mendapatkan pelayanan yang disertai dengan komponsasi' tertentu misalnya pembayaran.

Menurut Kepmenpan No. 63/KEP/M.PAN/7/ 2003, pelayanan publik adalah segala kegiatan pelayanan yang dilaksanakan oleh penyelenggara pelayanan publik sebagai upaya pemenuhan kebutuhan penerimaan pelayanan maupun pelaksanaan ketentuan peraturan perundang-undangan.

Lihat Hikmat Budiman (ed). 2005. Hak Minoritas; Dilema Multikulturalisme Indonesia, Jakarta. Yayasan Interseksi.

Penelitian ini menggunakan pendekatan kualitatif yang berusaha untuk menghasilkan data deskriptif, gambaran yang sistematis, faktual serta akurat mengenai fakta-fakta, sifat-sifat serta hubungan antara fenomena yang diamati dan dianalisis dengan pendekatan kualitatif dan hasil analisis ini akan dijelaskan dengan kalimat-kalimat yang dideskripsikan dan berusaha sedapat mungkinmemberikan kejelasan obyek dan subyek penelitian. Lihat. Lexy Moleong. 2001. Metode Penelitian Kualitatif. Bandung. Remadja Karya.

' J.S. Badudu dan Sultan Mohammad Zain. 2000. Kamus Umum Bahasa Indonesia. Jakarta. Pustaka Sinar Harapan.

"Lihat Sampara Lukman. 2000. Manajemen Kualitas Pelayanan. Jakarta, STIA LAN Press, h.80.

s Lihat lebih jauh, Sutopo dan Adi Suryanto. 2003. Pelayanan Prima: Bahan Ajar Diklat Prajabatan Golongan III. Jakarta, LAN. 
Dengan demikian, pelayanan publik adalah pemenuhan kebutuhan masyarakat oleh penyelenggara negara. Hal ini terkait dengan fungsi pemerintah dalam pelayanan publik yaitu enviromental service (pelayanan lingkungan), depelovment service (pelayanan pengembangan), dan protective service (perlindungan).

Dakwah keagamaan merupakan salah satu bentuk pelayanan keagamaan yang dilakukan pemerintah melalui Departemen Agama untuk memenuhi kebutuhan spritualitas masyarakat Indonesia. Secara khusus tugas Departemen Agama sebagai institusi negara yang bergerak di bidang pelayanan keagamaan demi meningkatnya keimanan dan ketakwaan masyarakat Indonesia yang agamis, adalah:

a. memantapkan fungsi, peran, dan kedudukan agama sebagai landasan moral, spritual, dan etika dalam penyelenggaraan negara serta mengupayakan agar segala peraturan perundangundangan tidak bertentangan dengan moral agama.

b. meningkatkan kualitas pendidikan agama melalui penyempurnaan sistem pendidikan agama sehingga lebih terpadu dan integral dengan sistem pendidikan nasional dengan didukung sarana dan prasarana.

c. meningkatkan dan memantapkan kerukunan hidup antar umat beragama sehingga tercipta kerukunan yang saling menghormati dalam semangat kemajemukan melalui dialog antar umat beragama dan pelaksanaan pendidikan agama secara deskriptif, tidak dogmatis untuk tingkat perguruan tinggi.

d. meningkatkan kemudahan umat beragama dalam menjalankan ibadahnya termasuk penyempurnaan kualitas pelaksanaan ibadah haji dan pengelolaan zakat, dengan memberikan kesempatan yang luas kepada masyarakat.

e. meningkatkan dan fungsi lembaga-lembaga keagamaan dalam ikut mengatasi dampak perubahan yang terjadi dalam semua aspek kehidupan untuk memperkukuh jati diri dan kepribadian bangsa Indonesia serta memperkuat kerukunan hidup bermasyarakat, berbangsa, dan bernegara.

Pengertian dakwah dalam konteks penelitian ini adalah tindakan sosial yang dilakukan oleh seseorang atau suatu institusi untuk menyampaikan ajaran dan nilai-nilai agama kepada masyarakat. Tindakan sosial berupa; 1) ceramah agama pada hari tertentu seperti Jumat, Bulan Ramadan, dan pada peristiwa sosial keagamaan seperti maulid, isra' mi'raj; 2) penyebaran informasi agama melalui buku, majalah, bulletin dan lain-lain; 3) tindakan paedagogik melalui pengajaran ajaran dan nilai agama di isntitusi pendidikan baik sekolah maupun madrasah.

Dakwah sendiri memiliki elemen-elemen penting, seperti tema dakwah, pelaksanaan dakwah, sasaran dakwah, strategi dakwah dan out-put yang dihasilkan oleh kegiatan dakwah keagamaan tersebut.'

\section{TEMUAN DAN PEMBAHASAN}

\section{Dinamika Kehidupan Sosial Keagamaan di Desa Suae.}

Untuk kasus Sulawesi Selatan, Desa Buae tergolong unik. Masyarakat Islam sebagai masyarakat dominan di Sulawesi Selatan (atau di Kabupaten Sidrap sendiri) ternyata berposisi sebagai masyarakat minoritas di Desa Buae. Ini sekaligus menunjukkan bahwa konstruksi tentang mayoritas sangat relatif dan sangat terkait dengan berbagai kategori sosial yang juga sangat relatif. Perasaan sebagai kelompok minoritas tidak hanya karena berbasis pada data demografis saja tetapi masyarakat Islam di Desa Buae ini memang merasakan itu sebagai fakta sosial. Setidaknya ungkapan itu muncul ketika peneliti berbincang-bincang dengan mereka. Salah seorang di antara mereka mengatakan: "kita cuma sedikit di sini, lebih banyak orang lain". Jumlah penduduk Desa Buae sekitar 3.085,2300 orang diantaranya adalah Tolotang. ${ }^{8}$

Desa Buae dikenal sebagai salah satu basis komunitas Tolotang (Towani) bersama dengan Kelurahan Amparita, dan Desa Otting. Komunitas Tolotang telah tinggal di Desa Buae sejak lama. Posisi

Lijan Poltak Simanjuntak. 2006. Reformasi Pelayanan Publik; Teori, Kebijakan, dan Implementasi. Jakarta, Bumi Aksara.

Lihat lebih jauh Syukir Asmuni. 1983. Dasar-Dasar Strategi Dakwah. Al-Ikhlas:Surabaya. Lihat pula Amrullah Ahmad. 1983. Dakwah Islam dan Perubahan Sosial. Prima Dua; Yogyakarta. Bandingkan dengan, M. Arifin. 2000. Psikologi Dakwah.Suatu Pengantar. Jakarta, Bumi Aksara

${ }^{\circ}$ Lihat BPS Kabupaten Sidenreng Rappang, 2008. Kecamatan Watangpulu dalam Angka. Pangkajene, Balai Pusat Statistik Kab. Sidrap. 
desa yang tidak jauh dari Amparita (pusat komunitas Tolotang) menyebabkan ekspansi warga Tolotang ke daerah ini dapatterjadi. Ekspansi terbesar komunitas Tolotang terjadi pada tahun 1950-an ketika peristiwa DI/TII terjadi. Pada saat itu, salah seorang pimpinan Tolotang mati terbunuh oleh pasukan DI/TII. Hal ini memicu terjadi arus pengungsian komunitas Tolotang ke daerah yang aman, terutama Amparita dan Buae.' Setelah situasi aman, para pengungsi ini tidak lagi berkehendak kembali ke Otting. Mereka lebih memilih menetap di Desa Buae hingga saat ini.

Kehidupan keagamaan masyarakat Islam di Desa Buae berjalan dengan baik, dan tidak terganggu dengan posisi mereka sebagai masyarakat minoritas. Masyarakat Islam Buae tetap menjalankan ibadah mereka, membangun masjid, dan menyetel suara kaset mengaji dengan keras sama seperti di daerah berbasis Islam lainnya, tanpa mengalami perasaan inferioritas. Ini karena relasi antar masyarakat Islam dan masyarakat Tolotang berjalan dengan baik dan harmonis. Mereka hidup dalam kebersamaan yang unik, toleran, dan menarik. Ruang-ruang sosial seperti masj id - dalam konteks tertentu- menjadi ruang sosial bersama masyarakat Desa Buae, tidak hanya dimiliki oleh masyarakat Islam sendiri. Misalnya ketika ada pengumuman pemerintah tentang persiapan desa menghadapi peringatan Hari Kemerdekaan 17 Agustus 1945, masjid sebagai ruang sosial yang efektif digunakan sebagai instrumen pengumuman. Suara loudspeaker masjid yang cukup keras dapat menjangkau sebagian besar rumah warga.

Masyarakat Islam Desa Buae sebagaimana masyarakat desa dapat dikategorikan sebagai masyarakat Islam tradisional. Mereka biasa menggelar acara barzanji pada acara aqiqah anak, perkawinan, naik rumah baru dan pada saat salah seorang warga melaksanakan ibadah haji. Beberapa orang masyarakat Islam bahkan masih menjalankan tradisi nenek moyang mereka seperti massorong (ritual sesajen di sungai dan ke gunung). Keberadaan corak tradisionalisme Islam akan terancam dengan munculnya kelompok-kelompok wahabis yang berada tidak jauh dari desa ini. Beberapa saat lalu, kaderkader dari kelompok Islam puritan pernah masuk di desa ini dan membid'ahkan kegiatan-kegiatan keagamaan masyarakat Desa Buae. Untungnya, beberapa tokoh agama desa cukup resisten sehingga penetrasi dari kelompok Islam puritan tidak berlanjut.
Hal yang menarik dari dinamika sosial keagamaan di Desa Buae adalah adanya perpindahan masyarakat Tolotang ke Islam yang terjadi hampir setiap tahun. Meski tidak ada catatan resmi mengenai jumlah masyarakat Tolotang yang telah beralih agama, namun diyakini proses ini telah berlangsung sejak lama dan ratusan orang Tolotang telah berpindah keyakinan. Pada medio Juni 2009, pihak KUA kecamatan Watangpulu mengislamkan sebanyak 123 warga Tolotang dari dua desa yaitu Desa Buae dan Desa Lonta Batang. 111 di antaranya berasal dari Desa Buae. Sebagian di antaranya adalah telah diislamkan beberapa tahun lalu, namun disyahadatkan kembali oleh pihak KUA Kecamatan Watangpulu. Proses perpindahan orang Tolotang menjadi Islam lebih banyak disebabkan oleh faktor perkawinan. Orang Tolotang yang akan menikah dengan orang Islam lebih banyak mengalah dan memilih menjadi Islam untuk mengikuti pasangannya. Meski begitu, ada juga beberapa orang yang masuk Islam melalui proses transformasi kesadaran. Mereka terbiasa bergaul dengan umat Islam dan memiliki ketertarikan dengan wacana keislaman. Seperti Dapri misalnya. Pemuda berusia sekitar 26 tahun ini masuk Islam sejak tahun 1996. Ia tertarik menjadi Islam setelah membaca buku-buku tentang Islam. Perasaannya tergugah dan akhirnya memilih masuk Islam. Ia pernah menjadi salah seorang aktivis remaja masjid di Buae sebelum akhirnya pindah ke daerah Benteng, Sidrap.

Meski proses perpindahan orang Tolotang menjadi Islam telah berlangsung cukup lama, hal itu tidak mempengaruhi relasi sosial antara masyarakat Islam dan Tolotang. Selain karena proses pengislaman diawali dengan "permintaan izin" kepada orang tua calon muallaf, juga karena sebagian besar muallaf adalah berasal dari kalangan orang biasa (to sama), bukan bagian dari hirarki uwa Tolotang, terutama uwa ienreki nanre (istilah untuk uwa atau pimpinan spritual Tolotang yang rumahnya dinaiki oleh warga Tolotang untuk mempersembahkan makanan, khas masyarakat Tolotang). Agak berbeda misalnya apabila yang masuk Islam adalah anak dari uwa. Biasanya terjadi proses yang lebih alot. Tetapi pada umumnya, masyarakat Tolotang tidak lagi terlalu memperdulikan jika salah seorang kerabat mereka masuk Islam. Mereka masih bisa hidup normal layaknya sebuah keluarga besar dengan perbedaan yang ada. Hal ini karena sejarah hidup orang Tolotang dan Islam telah terjalin sejak abad

'Lihat Saprillah. 2006. Siasat Lokalitas: Studi Tentang Strategi Komunitas Tolotang Mempertahankan Identitasnya. Makassar, Program Pascasarjana UNHAS. 
17 M ketika para pengungsi dari Wani Sengkang datang ke Sidenreng dan mendapatkan perlindungan dari Addatuang Sidenreng.

Faktor lain yang mempengaruhi kuatnya relasi Islam dan Tolotang adalah jaringan kekerabatan antar dua komunitas tersebut. Hampir seluruh masyarakat Islam di Buae (terutama penduduk asli Buae) memiliki hubungan kekerabatan dengan masyarakat Tolotang. Hal ini karena masyarakat Islam dan Tolotang Buae sebetulnya adalah masyarakat yang memiliki akar kultur yang sama sebagai masyarakat Bugis. Jaringan kekerabatan tidak putus karena adanya perbedaan agama, tetapi justeru menjadi alat kohesi yang sangat efektif antar dua komunitas yang berbeda agama tersebut.

Meski berbeda keyakinan, namun perfomance masyarakat Islam dan Tolotang tidak dapat dibedakan. Mereka sama-sama Bugis, bahasa yang digunakan sama, namayang digunakan relatif sama karena orang Tolotang sebagian mengadaptasi nama-nama dari Islam, begitu pula sebagian orang Islam menggunakan nama-nama adaptasi dari struktur tradisional, cara berpakaian sama-sama menggunakan sarung dan peci (masyarakat Tolotang bahkan dalam acara spritual mereka menggunakan sarung dan peci seperti layaknya orang Islam ketika shalat Jumat). Diffrensiasi kedua komunitas ini hanya terlihat pada hari tertentu, seperti pada hari Jumat dimana sebagian besar umat Islam berada di masjdi, atau pada saat ritual mappaenre inanre, dimana seluruh orang Tolotang berada di rumah uwa mereka untuk melaksanakan upacara ritual tersebut.

\section{Resources Keagamaan di Desa Buae.}

Desa Buae-dalam konteks keagamaan- bukan merupakan daerah basis pengembangan Islam di Sidrap. Hal ini terlihat dari kurangnya sumber-sumber pengembangan agama Islam di desa ini. Tidak ada pesantren atau madrasah baik tingkat dasar ibtidiyah terlebih lagi tingkat lanjutan (tsanawiyah atau aliyah). Warga desa yang ingin menyekolahkan anak mereka di sekolah berbasis Islam harus ke kota atau paling tidak di tempat-tempat yang ada pesantren di situ, seperti di Benteng, tempat Pesantren Al-Urwatul Utsqa, pesantren yang cukup melegenda di Kabupaten Sidenreng Rappang. Mungkin, karena jumlah masyarakat Islam yang cukup kurang di Desa ini yang menyebabkan kelompok-kelompok Islam tidak menjadikannya sebagai basis pengembangan Islam. Hal ini menyebabkan masyarakat Islam Buae harus mengelola sendiri dinamika keagamaan mereka.
Resources keagamaan di Desa Buae dapat terlihat pada tabel di bawah ini:

\begin{tabular}{|c|l|c|}
\hline No & Resources & Jumlah \\
\hline 1 & Masjid & 2 \\
\hline 2 & TPA & 1 \\
\hline 3 & PPPN/ Imam Desa & 1 \\
\hline 4 & Pegawai Sara' & 3 \\
\hline 5 & Guru Ngaji & 4 \\
\hline 6 & Majelis Taklim & 1 \\
\hline
\end{tabular}

Resources keagamaan yang terlihat pada tabel di atas dapat dibagi dua. Pertama, ruang sosial sebagai tempat kegiatan keagamaan berlangsung, yaitu masjid dan TPA. Dengan jumlah umat Islam yang tidak terlalu banyak, jumlah masjid tersebut dirasakan telah cukup dapat memenuhi kebutuhan umat Islam untuk melaksanakan ibadah shalat wajib, khususnya ibadah shalat Jumat. Masj id Nurul Iman yang terletak di pusat desa tidak hanya berfungsi sebagai tempat melakukan shalat bagi umat Islam, tetapi juga berfungsi sebagai tempat dimana informasi publik disampaikan. Misalnya pengumuman tentang bersih desa, pengumuman ada hajatan dan sebagainya. Dengan demikian, keberadaan masj id Nurul Iman menjadi sangat penting bagi masyarakat Islam di Desa Buae dan sekaligus masyarakat non-Islam yang berada di sekitar masj id. Selain masj id Nurul Iman, terdapat pula sebuah masjid di dusun Paosadae yang bernama masjid Ar-Rahmah. Masjid ini berukuran lebih kecil dari masjid Nurul Iman.

TPA (Taman Pengajian Alquran) Al-Ikhlas yang berdiri tahun2007 saat ini belum memiliki gedung sendiri. Tempat pelaksanaan kegiatan dilakukan di Gedung Sekolah Dasar Buae. Guru mengaji yang bertugas sebagai guru TPA adalah guru agama di SD tersebut. Jumlah siswa yang dikelola saat ini sekitar 20 orang anak. Hadirnya TPA-menurut La Bahang- adalah untuk menjawab kebutuhan masyarakat Buae atas pendidikan dan pengajaran Alquran sekaligus menggantikan peran sistem ngaji kampung yang mulai pudar. Di Buae masih ada dua orang guru ngaji kampung yang sudah berusia lanjut. Mereka masih membuka pengajian meski peminatnya sudah mulai menurun.

Sayangnya, desa ini tidak menyiapkan tempat pengajian khusus para muallaf. Padahal, mereka sangat membutuhkan pelajaran membaca Alquran sebagai basis pemahaman terhadap Alquran. Para muallaf ini tentu saja tidak dapat memahami Islam dengan baik jika mereka tidak tahu membaca Alquran. Mereka tidak dapat shalat dengan baik, karena hampir seluruh bacaan Shalat bersumber dari Kitab Alquran. 
Kedua, sumber daya manusia yang terdiri atas Pembantu Pencatat Nikah atau lebih dikenal dengan sebutan imam desa, pegawai sara' yang bertugas sebagai imam masjid, khatib rutin, dan muadzzin, serta guru ngaji sebanyak tiga orang. Dua di antaranya adalah guru ngaji kampung, sedangkan satu orang lainnya guru ngaji kontemporer yang melayani anakanak kampung di TPA.

Secara umum, ketersediaan sumber daya manusia yang mengelola dinamika keagamaan sudah mencukupi. Paling tidak, sudah ada orang yang mau secara rutin menyetel radio mengaji menjelang shalat, adzan, menjadi imam rawatib, dan menjadi khatib pada hari Jumat. Hal itu telah dapat memenuhi kebutuhan spritual rninimal masyarakat desa. Di samping itu, peran pemerintah Kabupaten Sidrap cukup baik dalam memperhatikan pegawai-pegawai sara' di Kabupaten Sidrap. Para pegawai sara' ini mendapatkan salary tiap bulannya meski jumlahnya tidak terlalu banyak.

Sejak tahun 2006, pihak pemerintah Kabuaten Sidrap telah rutin mengaanggarkan belanja daerah untuk memberi gaji pada pegawai sara' di masjid di kota dan desa di seluruh Kabupaten Sidrap. Langkah ini perlu mendapat apresiasi yang tinggi, karena bagaimanapun juga para pegawai sara' telah dengan tulus mengabdikan hidup mereka untuk melayani kebutuhan keagamaan masyarakat Islam di sekitarnya. Jumlah insentif yang diterima oleh pegawai sara dapat dilihat pada tabel dibawah:

\begin{tabular}{|c|l|l|l|}
\hline No & Pegawai Sara' & Tahun 2006 & Tahun 2009 \\
\hline 1 & Imam Desa & Rp. 80.000 & Rp. 160.000 \\
\hline 2 & Khatib & Rp. 60.000 & Rp. 120.000 \\
\hline 3 & Pegawai Sara lainnya & Rp. 50.000 & Rp. 100.000 \\
\hline
\end{tabular}

Persoalannya adalah ketiga pegawai sara' telah berusia lanjut dan tidak memiliki kemampuan yang baik untuk mengelola dakwah keagamaan. Akibatnya, pengelolaan dakwah di masjid (khususnya) berlangsung secara mekanik tanpa ada upaya kreatif untuk mendinamisasi dakwah keagamaan. Artinya, mereka hanya memposisikan diri sebagai pekerja masjid bukan bagian dari empowering masyarakat di bidang keagamaan.

\section{Pengelolaan Dakwah Keagamaan di Desa Buae}

Pengelolaan dakwah keagamaan di Desa Buae dapat dibagi dua. Pertama, program dakwah yang dilakukan pemerintah (khususnya Departemen Agama melalui KUA Watangpulu) melalui program penyaluran dai-dai ke desa-desa setiap hari Jumat. Sejauh ini, pro- gram itu berjalan lancar. Para dai menjalankan tugas untuk menjadi khatib Jumat. Begitu pula, pada bulan Ramadhan, KUA Watangpulu mengirim beberapa dai untuk berceramah di Masj id Nurul Iman, Buae. Selain pengiriman dai, KUA Watangpulu juga mulai gencar melaksanakan suscatim (kursus calon pengantin) yang bertujuan untuk memberikan dasar-dasar pelaksanaan nikah, pengucapan kalimah syahadat, dan tata cara mandi junub dll. Kursus Calon Pengantin ini dimaksudkan sebagai upaya untuk membangun keluarga sakinah sesuai dengan tuntunan Syariat Islam. Program Suscatim ini sendiri adalah program Departemen Agama yang telah lama diprogramkan, tetapi KUA Watangpulu baru melaksanakan program ini selama tiga tahun terakhir. Menurut KUA Watangpulu, pelaksanaan suscatim ini didasarkan pada kekhawatiran banyaknya calon pengantin yang tidak bisa mengucapkan syahadat, sigat ijab qabul dan tata cara mandi junub.

Program dakwah lain yang diinisiasi oleh pemerintah Kabupaten dan Departemen Agama Kabupaten Sidrap adalah pembentukan majelis taklim di beberapa desa termasuk Desa Buae. Di Desa Buae sendiri sejak tahun 2003 telah dibentuk majelis taklim yang dinamakan majelis taklim Nurul Iman (diambil dari nama masjid Desa Buae). Sayangnya, pembentukan majelis taklim tidak disertai dengan tindakan yang lebih nyata. Akibatnya, majelis taklim tersebut tidak berjalan selama beberapa tahun. Baru pada tahun 2009, majelis taklim ini diaktifkan kembali oleh tokoh agama setempat, dengan menggelar pengajian rutin setiap hari Jumat terakhir pada tiap bulannya.

Kedua, pengembangan dakwah yang dikelola oleh masyarakat. Tradisi keagamaan seperti aqiqah, syukuran naik haji, maulidNabi Muhammad, Isra' dan Mi'raj, dan pernikahan merupakan ruang sosial yang lazim digunakan sebagai ruang dakwah keagamaan. Hampir seluruh kegiatan keagamaan tersebut melibatkan seorang penceramah agama atau dai untuk memberikan tausiyah (nasihat) keagamaan. Pelibatan seorang dai dalam kegiatan keagamaan dilakukan secara individual, tanpa melalui intervensi pemerintah. Artinya, setiap pemilik hajatan mengundang secara langsung kepada dai untuk berceramah. Selain bersifat individual, beberapa kegiatan keagamaan dikelola oleh masyarakat secara bersama-sama, seperti kegiatan maulid nabi, isra' mi'raj, dan pengelolaan majelis taklim. Para pengurus masjid atau panitia hajatan memiliki tanggung jawab untuk mendatangkan seorang dai. 
Biasanya dai yang diundang adalah dai yang populer atau dai yang sesuai dengan "citarasa" masyarakat desa, paling tidak sang dai fasih berceramah dalam bahasa Bugis.

Kehadiran Majelis Taklim Nurul Iman menjadi salah satu media dakwah yang menyegarkan. Majelis Taklim ini dikelola untuk "mengawal" nalar keagamaan masyarakat khususnya pada dasar-dasar ajaran Islam. Oleh karena itu, tema-tema yang dikaji dalam majelis taklim lebih mengarah pada kajian fiqhi seperti thaharah (minggu pertama), dan tata cara shalat yang baik (pertemuan kedua), puasa (pada pertemuan ketiga) dan seterusnya. Namun, penjadwalan materi tidak dilakukan secara tertib. Kegiatan majelis taklim biasanya dilakukan pada sore hari, terutama ketika para petani pulang ke rumah selepas dari bekerja di kebun. Sejauh ini (paling tidak selama penelitian ini dilaksanakan), kegiatan keagamaan di majelis taklim dilakukan baru dua kali. Menarik untuk ditunggu, apakah kegiatan majelis taklim ini dapat berlangsung secara kontinyu.

Selain pengelolaan dakwah secara lahgsung oleh masyarakat desa, akses untuk memperoleh ceramah keagamaan juga dapat diperoleh melalui stasiun TV Kabel lokal seperti Alwarda Vision yang menyiarkan ceramah agama setiap hari dan Mitra TV yang menyiarkan ceramah agama setiap minggu sekali. Masyarakat Desa Buae yang memiliki saluran TV Kabel dapat dengan mudah mendengarkan ceramah agama yang tiap pagi (seusai shalat subuh) dan sore hari (sebelum magrib). Hampir seluruh ceramah yang ditampilkan oleh TV tersebut berbahasa Bugis, sehingga mudah dipahami oleh masyarakat desa pada umumnya.

Secara umum, pengelolaan dakwah keagamaan di Desa Buae lebih banyak menggunakan sistem oral (khutbah, atau ceramah) dengan memanfaatkan tradisi keagamaan masyarakat. Penggunaan media dakwah non-oral seperti poster dan leaflet yang memuat pesanpesan keagamaan dapat ditemukan di masjid Nurul Iman. Di dinding samping kanan masjid, tepatnya di depan tempat pengambilan air wudhu tertempel beberapa lembat poster yang memuat hadits-hadits tentang kebaikan dan keimanan. Begitu pula di dinding masj id bagian belakang ditempel beberapa poster yang memuat mutiara hikmah dan hari kemudian. Posterposter pesan keagamaan ini ditempel oleh seorang pemuda Desa Buae yang sedang belajar dan bekerja di salah satu pesantren di Kabupaten Sidrap. Sayangnya, jamaah masjid yang datang shalat di masjid tidak terlalu menghiraukan pesan-pesan dakwah di dinding tersebut. Boleh jadi, karena jamaah masjid sudah terlalu sering membaca atau memang mereka tidak menganggap pesan-pesan keagamaan di dinding masjid itu penting dibaca.

Dinamika dakwah keagamaan di pedesaan tidak terlepas dari peran aktif seorang aktor, bukan institusi. Biasanya aktor ini muncul dari kelas menengah desa yang memiliki pendidikan yang cukup baik dan perhatian serta pemihakan terhadap pengelolaan agama di desanya. Dalam konteks Desa Buae, aktor utamayang mendinamisasi dakwah adalah imam desa setempat (La Bahang). Ia tidak hanya berfungsi memfasilitasi kepentingan ritual masyarakat setempat seperti menjadi imam dan khatib, tetapi juga mendatangkan para dai dari luar desa untuk datang memberi penyegaran di Desa Buae. Terutama pada majelis taklim dan bulan ramadhan.

Peran organisasi keagamaan seperti NU, Muhammadiyah, MUI tampaknya tidak terlalu besar (kalau tidak ingin mengatakan tidak ada sama sekali) dalam pengembangan dakwah keagamaan di Desa Buae. NU yang memiliki program rutin lailatul ijtima (dua kali dalam sebulan), tidak mengagendakan desa ini sebagai tempat kegiatan, dan Muhammadiyah sebagai lembaga yang concern pada dunia pendidikan juga tidak menjadikan desa ini sebagai basis pendidikan. Sedangkan lembaga pendidikan pesantren biasanya hanya datang dan mengirim para dainya setiap bulan ramadhan saja.

Padahal masyarakat Islam di Buae sangat membutuhkan siraman spritual yang mencerahkan. Sebagian dari masyarakat Islam di Buae adalah muallaf. Mereka tidak memiliki latar belakang keagamaan yang cukup kuat, mereka tidak memiliki pendidikan agama, mereka tidak bisa membaca Alquran, dan mereka masuk Islam juga kebanyakan tidak dilandasi oleh kesadaran tetapi lebih karena kepentingan pernikahan dan karena itu dapat diduga semangat keberagamaan mereka lemah. Mereka tentu saja membutuhkan pencerahan spritual yang tidak formal tetapi subtantif. Artinya, kehadiran mereka sebagai masyarakat Islam baru seharusnya mendapat perhatian penting dari pemerintah dan departemen agama. Setidaknya untuk mengajarkan mereka membaca Alquran dan dasardasar pelajaran agama, agar spritualitas mereka tidak terlantar.

Memahami Dakwah Adaptif: Upaya Reposisi Dakwah dalam Masyarakat Islam Pedesaan. 
Pengelolaan dakwah keagamaan di Desa Buae selama ini hanya bersifat normatif dan mekanik. Artinya, pengelolaan dakwah dilakukan hanya untuk memenuhi standart kebutuhan fiqhi yang paling dasar, seperti shalat, puasa, dan sebagainya, dan karena itu bersifat mekanikal, rutin dan akhirnya tidak memiliki makna apa-apa. Dakwah tidak dilakukan dalam konteks perubahan situasi sosial. Hal ini-lah kemudian menyebabkan dakwah kehilangan ruhnya.

Para dai yang datang biasanya memang hanya sekedar menjalankan ritual tablig, menyampaikan tanpa peduli apakah masyarakat memahami atau tidak, mendengar atau tidak, berubah atau tidak. Ibaratnya, para dai hanya menjalankan fungsi-fungsi yang telah ditetapkan dalam mekanisme dakwah yang menjemukan. Apalagi, kebanyakan dai kurang kreatif dalam mengkonstruksi tema-tema dakwah. Biasanya mereka lebih memperhatikan aspek sekunder dari sistem dakwah yaitu cara menyampaikan, bukan pada apa yang disampaikan.

Padahal subtansi dakwah adalah mengajak manusia untuk berada dalam sistem kebenaran yang sesuai dengan situasi kemanusiaan. Dakwah menjadi alat refleksi untuk membawa masyarakat untuk merenungi posisi diri mereka dalam konfigurasi sosial dan sekaligus mendorong mereka untuk dapat memberi manfaat bagi lingkungan sosialnya. Dakwah merupakan aktualisasi nilai iman yang dimanifestasikan dalam sistem kegiatan manusia dalam bidang kemasyarakatan yang dilakukan secara teratur, untuk mempengaruhi cara merasa (feeling), cara berfikir, bersikap, dan bertindak.

Apa yang menyebabkan dakwah keagamaan menjadi kehilangan semangat perubahan dan cenderung bersifat mekanik belaka? Pengalaman dari lapangan menunjukkan bahwa tema-tema dakwah hanya difokuskan pada aspek normatif dari ajaranajaran Islam. Tema-tema tentang surga dan neraka, ketakwaan kepada Allah, dan wacana eskatologis lainnya menjadi tema utama dari para dai. Boleh dikatakan tidak ada dai yang mencoba keluar dari pakem-pakem normatifitas keagamaan. Kecenderungan yang berulang-ulang ini-lah kemudian dakwah menjadi kehilangan "pengaruh-nya" pada masyarakat. Masyarakat relatif telah hampir dapat mengerti apa yang telah dikatakan oleh para dai, karena telah diulang berulang-ulang kali oleh dai yang lain. Kalaupun ada yang berubah, lebih pada aspek retorisnya bukan aspek subtansi dakwahnya.
Terlebih-lebih lagi di pedesaan. Pelaksanaan dakwah keagamaan relatif jarang dilakukan. Pedesaan sejauh ini memang selalu terpinggirkan oleh pembangunan apapun. Para dai yang memiliki kemampuan baik rata-rata berada di pusat kota. Mereka sangat jarang pergi berceramah ke desadesa, di samping karena jarak yang relatif jauhjuga karena cost yang dikeluarkan relatif besar. Apalagi jika dai yang akan didatangkan memiliki reputasi cemerlang di perkotaan telah memiliki standar honor yang sulit dipenuhi oleh masyarakat pedesaan. Hal ini-lah kemudian yang menyebabkan dinamika keagamaan di kalangan masyarakat pedesaan menjadi beku, statis dan cenderung mempertahankan status quo. Seorang yang bertugas sebagai imam dan khatib biasanya bertahan sampai mati, kecuali ia dengan kerelaan mengundurkan diri.

Reposisi dan reinterpretasi dakwah keagamaan menjadi sangat penting karena dakwah keagamaan memiliki peran dan posisi yang sangat strategis. Dakwah keagamaan rutin dilakukan melalui lokus sosial seperti Shalat Jumat, aqiqah, peraikahan, ramadhan, dan lain-lain. Artinya, dalam setiap minggunya, masyarakat Islam wajib mendengarkan dakwah keagamaan. Situasi ini sesungguhnya sangat potensial untuk melakukan perubahan, apabila dakwah keagamaan dapat dikelola dengan baik.

Dakwah adaptif merupakan alternatif untuk mengembalikan "khittah" dakwah sebagai instrumen pengelolaan moralitas masyarakat dan sekaligus mengembalikan para dai sebagai "agen perubahan", bukan agen dari "sistem kekuasaan yang sedang berlangsung". Bagaimana dakwah adapatif dilakuan? Dakwah adaptif dimulai dari pemetaan isu-isu krusial yang sedang terjadi dan mungkin akan terjadi di dalam masyarakat. Para dai paling tidak memiliki pemetaan yang lengkap tentang daerah yang akan menjadi sasaran dakwahnya. Bahasa, potensi ekonomi, politik, sosial, kultural yang dimiliki dan dipraktekkan oleh masyarakat harus diketahui oleh para dai agar ia dapat dengan mudah melakukan transformasi pengetahuan. Oleh karena itu, para dai bukanlah orang yang terasing dari lingkungan sosial masyarakat atau para dai harus raj in "membaca" situasi sosial serta pergeseran perilaku yang sedang terjadi di masyarakat.

Isu yang penting dalam masyarakat Buae adalah isu tentang penghargaan antar sesama (pluralisme atau 
multikulturalisme agama) dan isu agraris. Potret masyarakat Buae adalah masyarakat beragam. Perbedaan teologis antara masyarakat Islam dan masyarakat Tolotang telah berlangsung sekian lama. Rajutan kerukunan sosial sejauh terjalin dari adanya ikatan kekerabatan antara dua masyarakat. Namun fenomena munculnya gerakan kelompok Islam puritan yang telah memiliki agen dari masyarakat setempat merupakan ancaman yang sewaktu-waktu dapat menimbulkan social crash. Kelompok Islam puritan memiliki basis ideologis yang sangat berlawanan dengan masyarakat Islam Buae yang tradisionalis dan masyarakat Tolotang yang menganut kepercayaan lokal. Bagi kelompok puritan, praktik ritual yang dilakukan oleh orang Islam sebagian adalah bid'ah dan praktik ritual komunitas Tolotang adalah musyrik. Salah satu kasus di Buae, salah seorang kelompok Islam dari pesantren tertentu di Sidrap pernah melakukan dakwah yang membid'ahkan kegiatan masyarakat Islam Buae dan menganggap praktik ritual Tolotang adalah kemusyrikan. Ingat, masyarakat Tolotang pada zaman DI/TII adalah salah satu target operasi karena kepercayaan mereka yang dianggap sangat bertentangan dengan agama Islam. Oleh karena itu, dakwah tentang perlunya saling menghargai harus terus menjadi tema yang penting untuk dapat melanggengkan "keharmonisan sosial" antara masyarakat Islam.

Isu kedua adalah isu agraris. Masyarakat Buae adalah sebagaian besar petani. Mereka biasa menghabiskan waktu di kebun atau sawah hingga sore hari. Pertanian adalah kehidupan mereka. Oleh karena itu, tema dakwah berbasis etos kerja, bekerja adalah ibadah, dan motivasi bekerja, serta isu-isu berbasis agraria seyogyanya menjadi salah satu tema penting dalam dakwah.

\section{PENUTUP}

\section{Kesimpulan}

Pengelolaan isu-isu berbasis kebutuhan masyarakat seperti isu pluralisme, lingkungan, pertanian, ekonomi, dan lain-lain adalah upaya untuk mengembalikan fungsi dakwah sebagai media perubahan sosial berbasis agama. Selain itu, untuk menghilangkan kejenuhan terhadap tema-tema keagamaan yang bersifat normatif tadi. Dengan demikian, dakwah keagamaan tidak hanya difungsikan secara formalistik tetapi benar-benar bagian dari pengembangan dinamika masyarakat.
Dakwah adaptif mengandaikan keterlibatan semua instrumen keagamaan baik pemerintah maupun organisasi masyarakat (terutama NU dan Muhammadiyah) dan masyarakat itu sendiri untuk berperan aktif di dalamnya. Dakwah tidak hanya dikonstruksi melalui sistem ceramah yang monoton, tetapi lebih dari itu dakwah dikonstruksi dengan menggunakan sistem advokasi dan pengorganisasian, dan karena itu ruang dakwah tidak hanya terbatas pada masjid, even-even keagamaan, tetapi juga pada kehidupan masyarakat sehari-hari, di sawah, kebun, dan sebagainya.

\section{Rekomendasi}

Berdasarkan pada temuan penelitian di atas, peneliti merekomendasikan beberapa hal:

1. Banyak orang Tolotang masuk Islam membutuhkan pengajaran keagamaan, khususnya membaca Alquran. Sejauh ini perhatian terhadap kasus ini sangat lemah. Oleh karena itu, pemerintah kabupaten dan departemen agama perlu membentuk lembaga atau mengangkat seorang guru mengaji yang khusus mengajari para muallaf yang telah berusia dewasa.

2. Perlu diadakan workshop perumusan dan penyusunan tema-tema dakwah adaptif (atau apapun istilahnya) yang melibatkan dai-dai yang selama ini sering melakukan dakwah di pedesaan. Workshop ini diharapkan melahirkan tema-tema dan sekaligus buku khutbah yang adaptif dengan lingkungan pedesaan.

3. Perlu diprogramkan riset aksi atau particoatory action research (PAR) Untuk pengembangan dakwah keagamaan berbasis masyarakat pedesaan.

4. Sebaiknya, departemen agama menempatkan seorang tenaga penyuluh di setiap desa, atau paling tidak mengangkat seorang pembantu penyuluh yang memiliki kualifikasi yang baik dari desa tersebut (seperti tenaga PPN) untuk melaksanakan dakwah keagamaan.

5. Perlu kaderisasi dai yang diambil dari masyarakat pedesaan tersebut.

\section{Ucapan Terima Kasih}

Ucapan terima. kasih diperuntukkan kepada Kepala Balai Penelitian dan Pengembangan Agama Makassar yang telah mengikutkan saya dalam penelitian ini. Selain itu, ucapan terima kasih kepada 
semua informan yang telah memberikan data-data dalam penelitian yang terkait dengan dakwah keagamaan, bukan untuk orang desa. Juga ucapan terima kasih kepada rekan sejawat yang telah mendukung, memberikan kritik, saran, dan diskusi mengenai isi tulisan ini.

\section{DAFTARPUSTAKA}

Ahmad, Amrullah. 1983. Dakwah Islam dan Perubahan Sosial. Yogyakarta: Prima Dua.

Asmuni, Syukir. 1983. Dasar-Dasar Strategi Dakwah. Surabaya: Al-Ikhlas.

Badudu, J.S dan Sultan Mohammad Zain. 2000. Kamus Umum Bahasa Indonesia. Jakarta: Pustaka Sinar Harapan.

BPS Kabupaten Sidenreng Rappang: 2008. Kecamatan Watangpulu dalam Angka. Pangkajene: Balai Pusat Statistik Kab. Sidrap
Bryan S. Turner. 1991. Agama dan Teori Sosial. Yogyakarta: Ircisod.

Budiman, Hikmat (ed). 2005. Hak Minoritas; Dilema Multikulturalisme Indonesia. Jakarta. Yayasan Interseksi.

Lukman, Sampara. 2000. Manajemen Kualitas Pelayanan. Jakarta: STIA LAN Press.

M. Arifin. 2000. Psikologi Dakwah;Suatu Pengantar. Jakarta: Bumi Aksara

Moleong, Lexy. 2001. Metodologi Penelitian Kualitatif. Bandung. Remadja Karya.

Saprillah. 2006. Siasat Lokalitas; Studi Tentang Strategi Komunitas Tolotang Mempertahankan ldentitasnya. (Tesis). Makassar: PascasarjanaUniversitas Hasanuddin.

Simanjuntak, Lijan Poltak. 2006. Reformasi Pelayanan Publik; Teori, Kebijakan, dan Implementasi. Jakarta: Bumi Aksara.

Sutopo dan Adi Suryanto. 2003. Pelayanan Prima: Bahan Ajar Diklat Prajabatan Golongan III. Jakarta: LAN. 